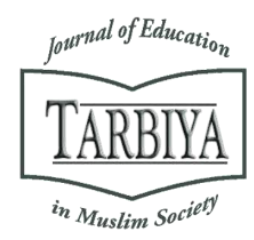

Available online at TARBIYA: Journal of Education in Muslim Society Website:

http://journal.uinjkt.ac.id/index.php/tarbiya

TARBIYA: Journal of Education in Muslim Society, 7(2), 2020, 167-182

\title{
PROMOTING EFL STUDENTS' ACADEMIC CHARACTER THROUGH INSTRUCTIONAL PRACTICE IN REVOLUTION INDUSTRY 4.0
}

\author{
Hadiyanto \\ Universitas Jambi, Indonesia \\ E-mail: hadiyanto@unja.ac.id
}

Received: $25^{\text {th }}$ September 2020; Revised: $28^{\text {th }}$ November 2020; Accepted: $28^{\text {th }}$ December 2020

Abstract

This study investigates English as a Foreign Language (EFL) teachers' instructional practices in developing students' academic character. Self-evaluation questionnaires were distributed to 37 teachers, and 26 were returned. Seven Focus Group Discussion (FGD) participants were selected based on their availability. The study reveals that EFL teachers averagely facilitated students to enhance their academic character and rated developing students' academic character at a critical level. There are five majors handicap for EFL teachers in developing students' academic character. First, the curriculum does not integrate the academic character with the courses offered. Second, implementing academic character into the curriculum is time-consuming. Besides, teachers assume that their students can automatically apply academic character in their life without it should be integrated into the courses. Lastly, the teaching loads that teachers must do are enormous. Drawing from those problems, several recommendations are proposed: curriculum policy at the university level should be taken, providing a standard syllabus application, providing a simple evaluation system, and freeing EFL teachers from bureaucratic and administrative burdens. Furthermore, the current study has sounded the research result to university academic authority and recommended that the department embed students' academic character in learning and suggested the EFL teachers embed and assess students' academic character development through instructional practices.

Keywords: higher education; EFL Students Character; EFL Teacher; teaching and learning

\section{Abstrak}

Studi ini menyelidiki praktik instruksional guru English as a Foreign Language (EFL) dalam mengembangkan karakter akademik siswa. Kuesioner evaluasi diri dibagikan kepada 37 guru, dan 26 dikembalikan. Tujuh peserta Focus Group Discussion (FGD) dipilih berdasarkan ketersediaan mereka. Studi ini mengungkapkan bahwa guru EFL rata-rata memfasilitasi siswa untuk meningkatkan karakter akademis mereka dan menilai pengembangan karakter akademis siswa pada tingkat kritis. Ada lima jurusan yang menjadi kendala bagi guru EFL dalam mengembangkan karakter akademik siswa. Pertama, kurikulum tidak mengintegrasikan karakter akademik dengan mata kuliah yang ditawarkan. Kedua, menerapkan karakter akademik ke dalam kurikulum memakan waktu. Selain itu, guru beranggapan bahwa siswanya dapat secara otomatis menerapkan karakter akademik dalam kehidupannya tanpa perlu diintegrasikan ke dalam mata pelajaran. Terakhir, beban mengajar yang harus dilakukan guru sangat besar. Berangkat dari permasalahan tersebut, beberapa rekomendasi diusulkan: kebijakan kurikulum di tingkat universitas harus diambil, penyediaan penerapan silabus yang standar, penyediaan sistem evaluasi yang sederhana, dan membebaskan guru EFL dari beban birokrasi dan administrasi. Selanjutnya, penelitian ini telah menjajaki hasil penelitian kepada otoritas akademik universitas dan merekomendasikan agar departemen tersebut menanamkan karakter akademik siswa dalam pembelajaran dan menyarankan guru EFL untuk menanamkan dan menilai pengembangan karakter akademik siswa melalui praktik pembelajaran.

Kata kunci: pendidikan tinggi; Karakter Siswa EFL; Guru EFL; mengajar dan belajar

How to Cite: Hadiyanto. (2020). Promoting EFL Students' Academic Character Through Instructional Practice in Revolution Industry 4.0. TARBIYA: Journal of Education in Muslim Society, 7(2), 167-182. doi:10.15408/tjems.v7i2.18998.

Permalink/DOI: http://dx.doi.org/10.15408/tjems.v7i2.18998 


\section{Introduction}

Though teaching and learning become digital, the human' role can not be replaced or neglected (Hadiyanto et al., 2018; Rusijono and Khotimah, 2018). Digital technology is only a content delivery tool, while humans are the controller of the technology itself. Therefore, integrating the character into teaching and learning in the revolution industry 4.0 becomes more critical (Woo, 2018). Students may be not only prepared with the ability to use digital machines, but they also must have an excellent character to empower their skills. In other words, the use of e-learning, online learning, e-resources and web-based learning may not neglect students' academic character development. Teachers should be aware and ready to develop students' academic character through conventional and digital system learning (Ristekdikti, 2018).

A teacher may not only focus on syllabus and students' academic achievement and neglect character practices in learning. Neglecting character virtues in the process of learning will impact on low professionalism of graduate at the workplace. Especially for English education graduate, it will impact the virtues of their low character as English teachers.

The research suggests that academic character development is best facilitated by directly giving students practice and not merely demonstrating what they have to do. Integrating academic character and learning activities should be in natural settings in both conventional and digital systems. In the end, it is expected that the university can generate students with good character attributes. As stated by the Indonesian Ministry of Education (2013), the integration of character into teaching and learning activities should contribute to graduates' professional attitude and being good citizenship as an employee, employer, worker, a professional and in all professions (Derlina et al. 2015; Ristekdikti, 2015).

The importance of developing students' academic characters through instructional practice is truly uncontested. However, there is still a lack of research, survey and evaluation related to the issue. Therefore, the current study has been conducted to gain the teachers' perceptions of developing students' academic character through the teaching and learning process. This paper reported English Education students' academic character development based on EFL teachers' instructional practice.

\section{Defining Art Academic Character}

Character points to something deeply rooted in personality, to its organising principle that integrates behaviour, attitudes and values (Lapsley \& Narvaez, 2006). Inner humanism values that can be internalised and applied in one behaviour, whether in daily, social activities, and workplace characteristics, are about norms, habits, behaviors, cultures, customs, and aesthetics (Woo, 2018; Vezzuto, 2004). In the Indonesian context, the character is the values according to religious norms, cultural, legal /constitutional, customs, and aesthetics (MONE, 2010). Therefore, character education is a system to build students' values, attitude, behaviour, and norms to be practised in their life as a good citizen. (Berkowitz \& Bier, 2004).

Referring to the Indonesian National curriculum, a character refers to the attitude and social value that students must have from the beginning of education. In this study, academic character qualities represent the ability to feel, know, express, and practice humanism values in learning activities, including in the University context. Academic character is humanism character applied in the classroom, designing specific course, applying in the learning process, working on their assignment, and interacting with their classmate and teachers during learning 
activities (Bialik et al. (2015). Academic characters are also applied in scoring students' assignment, learning activities such as in discussion and presentation (Bialik et al., 2015; Vezzuto, 2004).

Seven academic characters primarily need to be integrated into the learning process and activities; honesty, appreciation, tolerance, discipline, patient, confidence and responsibility (Hadiyanto, 2018; Derlina et al., 2015; Person et al., 2009; Bath et al., 2004). Each construct of character is defined as follow:

Honesty refers to students' automatic action and expression in confessing and reporting the truth, facts, his/her shortcomings, friends' strengths, and learning from authentic resources (Veugelers, 2011; Person et al., 2009; Vezzuto, 2004).

Appreciation is about how the students show their positive attitudes, words, and actions in appreciating their friends' ideas, contributions and works, and not condescending or blaming their friend. (Veugelers, 2011; Person et al., 2009).

Tolerance refers to students' reflection and action to accept the differences of personality, abilities, attitudes, gender, social status and change the differences to be more beneficial for achieving maximum learning objectives (Veugelers, 2011, Person et al., 2009).

Discipline is students' consistency in good time and works management, following the rules of academics, class attendance, completing and submitting task on time, and achieving learning goals (Veugelers, 2011; Person et al., 2009: Vezzuto, 2004).

Patience is about maintaining the spirit of learning and emotional sustainability in doing assignment and tasks, exchanging ideas in a discussion, facing and resolving learning problems until learning goals achieved (Person et al., 2009; Vezzuto, 2004).

Confidence is the student's ability to present himself, such as ability, ideas, skills, etc., and the ability to relieve nervous, anxious, depressed and tense in learning activities, including giving writing and oral presentation (Person et al., 2009).

Responsibility is defined as students' action in completing assignments, tasks and learning outcomes by their effort and taking and completing a part and as a group member, a group leader and a moderator in a discussion. (Veugelers, 2011; Person et al., 2009: Vezzuto, 2004).

\section{Integrating Character into Instruction}

According to the Mendiknas- Indonesian Ministry of National Education (2011), character education in the social context is a systematic and integrated approach involving families, educational units, government, civil society, legislative members, media, the world of business, and industry in implementing national cultural values into life activities. However, character education in the Indonesian national curriculum of education defined as an effort to instil good habits (habituation) to the students through the learning process, starting from primary school to university. Implementing character education at school and university is done by carrying out character values through all learning subjects. Character is not taught through a particular subject, but students learning activities in a subject. Character is not the content of material but attitude, behaviour values of learning (Ristekdikti, 2015). Students take action and act based on their gifted values and personality; however, it will be worked when teachers can guide and control the students into integrated and natural atmosphere learning. Trianto (2007) suggests ten learning models of 
integration character into education and training; fragmented model, connected model, nested model, sequenced model, shared model, webbed model and threaded model, integrated model, immersed model and networked model. However, ten models can be classified into three main models as follows: 1) Interdisciplinary science: which belongs to this type is the fragmented model, the connected models, and the nested model; 2) Interdisciplinary science includes a sequenced model, shared model, webbed model, threaded model, and integrated model; 3) Intra-disciplinary science contains immersed and networked models. 1 and 2 have similar name?

This survey study refers to theoretical understandings of the Connected Model. The study assumed that students' academic character development is integrated through the teaching and learning process. The model of integration is described in the conceptual framework part.

\section{Conceptual Framework}

The definition of a component of academic character had been discussed in the previous part. Academic character instilled in students through the learning process. Teachers should guide, correct and advise students to improve their academic character during learning activities. The EFL teachers' role is crucial for creating a climate for students in the classroom to achieve academic character development goals. Beside encouraging individual students to develop their knowledge, competencies and grades, EFL teachers need to create situations and inspire students to display academic character behavior during learning activities, such as in discussion, presentation and group work activities.

Figure 1 illustrates the conceptual framework of integrating students' academic character into subject teaching and learning. The conceptual framework is developed based on literature analysis from Hadiyanto, 2019a;
Hadiyanto, Fajaryani \& Masbirorotni, 2018; Ristekdikti, 2015; Bialik, Bogan, Fadel \& Horvathova, 2015; Derlina, Sabani, Satria, Mihardi, 2015; Djailani, 2013; Person, Ann, Hgue-Angus, Malone, 2009; Fogarty \& Stoehr, 2008; Vezzuto, (2004). The first part is the subject's instructional design, including subject content and teaching and learning design. The instructional design should be prepared systematically and designed to give students a vast opportunity to expose their genuine character without any fear through their learning activities. The second part illustrates teacher instructional practices that consist of teachers' role, learning activities, students' engagement and academic character practices. The teacher role is to manage the classroom, implement teaching and learning strategies, and engage students in learning activities. The teacher must seek appropriate situations to illustrate, exemplify, guide, control, and advise students to improve their academic character. The instructional practice must ensure students character development occurred during their learning activities. The whole teaching process and learning at the English Education program are expected to attribute students with a higher quality of academic characters.

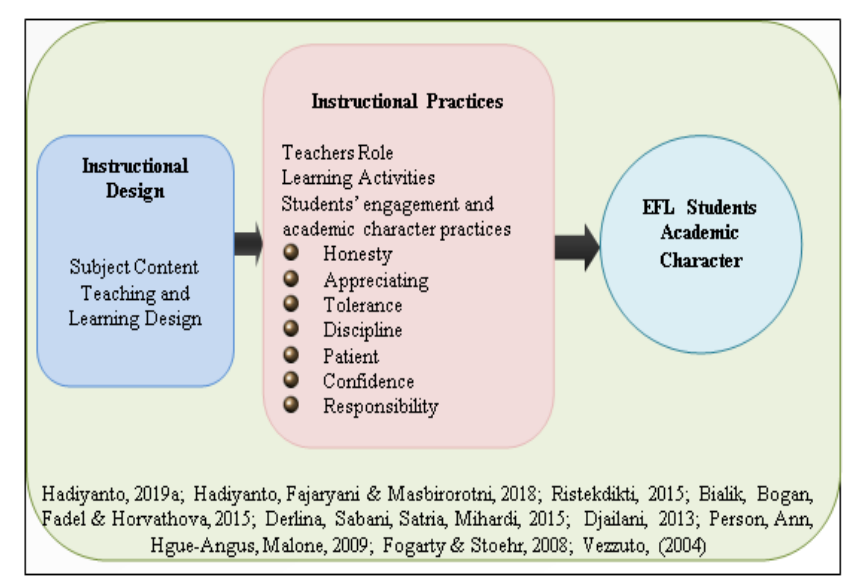

Figure 1. Conceptual framework of the study 


\section{Method}

The site of the survey study was at the English Education Department of a University in Indonesia. English teachers were the target of the population. The mixed quantitative and qualitative method were applied in this research. However, the quantitative method was the primary method of this research, while the qualitative method was applied to acquire more information related to quantitative findings. A self-report questionnaire was developed for gathering quantitative data, while FGD was applied for getting more information related to quantitative data findings.

The questionnaire as the main instrument of data collection consisted of two parts. The first part was gathering EFL teachers' demographic background, while the second was the central part of the questionnaire to gather respondents' responses on students' academic character development in instructional practices. A FiveLikert scale, 1 to 5, stars from never, rarely, sometimes, often, or very often were applied in responding to each statement.

The indicator of students' academic characters' development was developed from previous literature presented by Bialik, Fadel and Horvathova (2015), Ristekdikti (2015), Wilson. et al. (2014) and Vezzuto, (2004). Looking specifically into each definite academic character, eight items were applied for measuring honesty, seven items for measuring appreciating, five items for measuring tolerance, eight items for measuring discipline, eight items for measuring patient, six for measuring confidence and seven items for measuring responsibility. Descriptive analysis, frequency, percentage and mean score were used to report research findings. The mean score of the respondents' level of instructional practices is descriptively calculated and interpreted in five levels, as shown in Table 1.
Table 1. Interpretations of mean scores

\begin{tabular}{ll}
\hline Mean Score & Interpretation \\
\hline 1.00 to 1.80 & Very Low \\
1.81 to 2.60 & Low \\
2.61 to 3.40 & Average \\
3.41 to 4.20 & High \\
4.21 to 5.00 & Very High \\
\hline
\end{tabular}

As shown in Table 1, a mean score between 1.00 and 1.80 indicated a deficient level of core competencies, a mean score between 1.81 and 2.60 a low level, a mean score between 2.61 and 3.40 a medium level, a means scores between 3.41 and 40 a high level of mean score.20, 4.21 and 5.00 a very high level of core competencies.

FGD was conducted to follow up quantitative findings, awareness of the importance of character integration in the classroom, and mainly search on the kind of handicaps and teachers' solution in integrating the academic character into teaching and learning. Seven EFL teachers were selected based on their availability, and they were not respondents to questionnaire data collection. The analysis was conducted by getting the conclusion of each discussion topic. The result is displayed by the main topic and a conclusive quotation of FGD participant statements.

\section{Validity and Reliability Testing}

The reliability and validity test of the questionnaire results from the Overall Cronbach alpha coefficient at .919 , while all constructs also yielded a Cronbach alpha value of .70 and above. The value means that the instrument used in this research obtain high reliability. Furthermore, all academic character constructs also show corrected item-total correlation value at 0.30 and above (Pallant, 2011; Hair et al., 2006). In conclusion, the instrument is reliable and valid for measuring the EFL teachers' instructional practices for the sake of developing academic characters. 


\section{Respondents and Participant Profile}

Twenty-six of 37 participants had completed the questionnaires, while 11 of them has not returned the questionnaire. Respondents by age were ranged from 28 to 57 years. By gender, $11(40 \%)$ participants were male and 15 (89\%) females. By educational background, 22 $(84.6 \%)$ of the participants had a master degree, and four $(15,4 \%)$ had $\mathrm{PhD}$ degrees. By teaching experience, twelve (46\%) of them had experience from 5 to 10 years, seven (25.9\%) had experience from 11 to 15 years, and nine $(33 \%)$ has experience 16 years and above.

Out of 26 respondents, seven lecturers also participated in the FGD session. Five of the informants are female, and two others male. By educational background, all of the participants had a master degree. Two of them had teaching experience of 11 years, four had 9-10 years, and one possessed seven years of teaching experience.

\section{Results and Discussion}

Instructional Practices and importance level of Academic Character in Teaching and Learning Process

Figure 2 illustrates teachers' instructional practices and the importance of students' academic characters development. Teachers rated their instructional practices to enhance student's academic character is at a mean score of 2,97 (average level), while the critical level of students' academic character development is rated at 4.12 (High level) or closed to a critical level. Looking at every component of the characters, teachers' instructional practices in enhancing students' appreciating is at the highest mean score (3.25) and then it is followed by confidence $(3,24)$, tolerance (3.02), discipline $(2,96)$, responsibility (2.84), honesty $(2,81)$ and patience (2.75). All of the academics mean scores of the components of the character are at an average level. The findings imply that the teachers' instructional practices in enhancing student's character were not encouraging. However, teacher perceived the important level of enhancing students' confidence $(4,36)$ and appreciating $(4,35)$ at a very high level, while the importance level of enhancing students' honesty $(4,10)$, tolerance $(4,16)$, discipline $(4,18)$, patience $(3,91)$ and responsibility $(3,87)$ are at a high level. Teachers realised that academic character was essential to be promoted in the teaching and learning process.

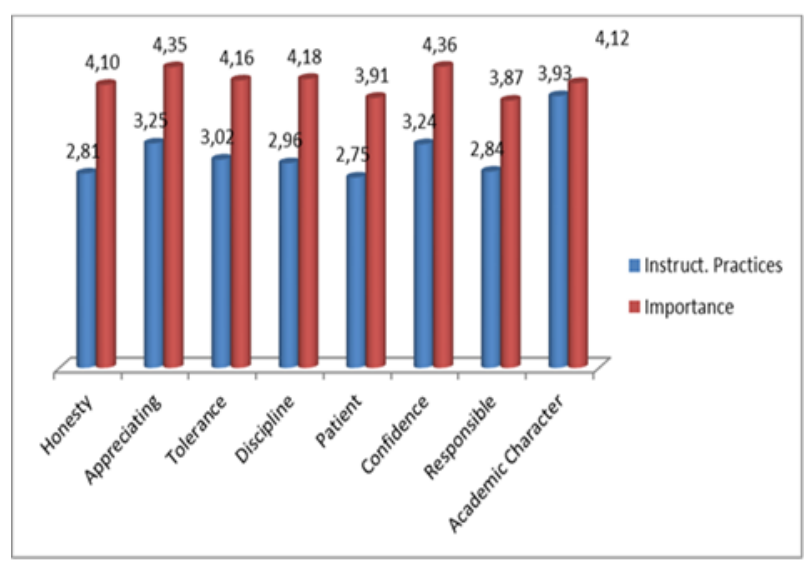

Figure 2: Level of Teachers' Instructional Practices and Importance

Instructional Practices and importance level of Honesty in the Learning Process

Table 1 displays teachers' instructional practices and the importance of promoting students' honesty in the learning process. Overall, teachers' instructional practices to encourage students' honesty in the learning process is at an average level $(2,81)$, while the level of importance of honesty in the learning process is at the top of the high mean score $(4,10)$. In more detail, teachers rate one indicator of honesty at a low level of instructional practices, it is indicator $\mathrm{H} 6$, and all other honesty indicators are in the range mean score of 2.61 3.40 or at an average level. In contrast, teachers 
perceive a level of importance of honesty in statement number $\mathrm{H} 3, \mathrm{H} 5$ and $\mathrm{H} 8$, while statements number $\mathrm{H} 1, \mathrm{H} 2, \mathrm{H} 4, \mathrm{H} 6$, and $\mathrm{H} 7$ are rated at a high level.

Table 1. Mean Score of Instructional practices and Importance Level of Honesty

\begin{tabular}{|c|c|c|c|c|c|c|}
\hline \multirow[t]{2}{*}{ Honesty } & \multicolumn{3}{|c|}{$\begin{array}{l}\text { Instructional } \\
\text { practices }\end{array}$} & \multicolumn{3}{|c|}{ Importance level } \\
\hline & $\overline{\mathrm{x}}$ & Std. & $\mathrm{L}$ & $\overline{\mathrm{x}}$ & Std. & $\mathrm{L}$ \\
\hline $\begin{array}{l}\text { H1. Asking } \\
\text { students for telling } \\
\text { what they can do } \\
\text { and can not group } \\
\text { member in a } \\
\text { project. }\end{array}$ & 2.69 & 0.68 & Av. & 4.00 & 0.75 & $\mathrm{H}$ \\
\hline $\begin{array}{l}\mathrm{H} 2 . \quad \text { Asking } \\
\text { students to admit } \\
\text { friends' strength in- } \\
\text { class activities. }\end{array}$ & 2.62 & 0.80 & Av. & 3.85 & 0.97 & H. \\
\hline $\begin{array}{l}\text { H3. Asking } \\
\text { students about their } \\
\text { problem and } \\
\text { weaknesses during } \\
\text { the study. }\end{array}$ & 2.96 & 0.77 & Av. & 4.44 & 0.71 & V.H \\
\hline $\begin{array}{l}\text { H4. Asking } \\
\text { students for telling } \\
\text { true resources in oral } \\
\text { and } \quad \text { writing } \\
\text { presentation. }\end{array}$ & 2.85 & 0.61 & Av. & 4.12 & 0.77 & $\mathrm{H}$. \\
\hline $\begin{array}{l}\text { H5. Asking } \\
\text { students for } \\
\text { controlling their self } \\
\text { for not presenting } \\
\text { and reporting fictive } \\
\text { data }\end{array}$ & 2.95 & 0.72 & $\mathrm{Av}$ & 4.23 & 0.71 & V.H \\
\hline $\begin{array}{l}\text { H6. Asking } \\
\text { students for copying } \\
\text { and pastingto work } \\
\text { on my assignments. }\end{array}$ & 2.27 & 0.78 & Lo. & 3.52 & 1.34 & $\mathrm{H}$ \\
\hline $\begin{array}{l}\text { H7. Explain } \\
\text { the materials clearly } \\
\text { and repeat it in } \\
\text { order to avoid } \\
\text { students' pretending } \\
\text { in understanding } \\
\text { material explained. }\end{array}$ & 3.04 & 0.60 & Av. & 4.13 & 0.55 & $\mathrm{H}$ \\
\hline $\begin{array}{l}\text { H8. Giving } \\
\text { appraisal } \\
\text { students' thought, } \\
\text { even it is not } \\
\text { correct. }\end{array}$ & 3.12 & 0.71 & Av. & 4.31 & 0.84 & V.H \\
\hline Overall & 2.81 & 0.43 & Av. & 4.10 & 0.58 & $\mathrm{H}$ \\
\hline
\end{tabular}

Instructional practices and importance level of Appreciating in Learning Process

Table 2 reveals that teachers encouraged appreciating the learning process at the mean score's average level (3.24). Six of seven indicators of appreciating yield mean score at an average level (mean between 2.41-3.20). However, indicator number 15 is applied in the learning process at a high level. Interestingly, teachers' perception of an essential level of appreciating in the learning process is a very high level (mean 4,35), and all indicators of appreciating are rated at a very high level (4.21 5.00) except indicator number I1 which is at a high level (4.12).

Table 2. Mean Score of Effort and Importance Level of Appreciating

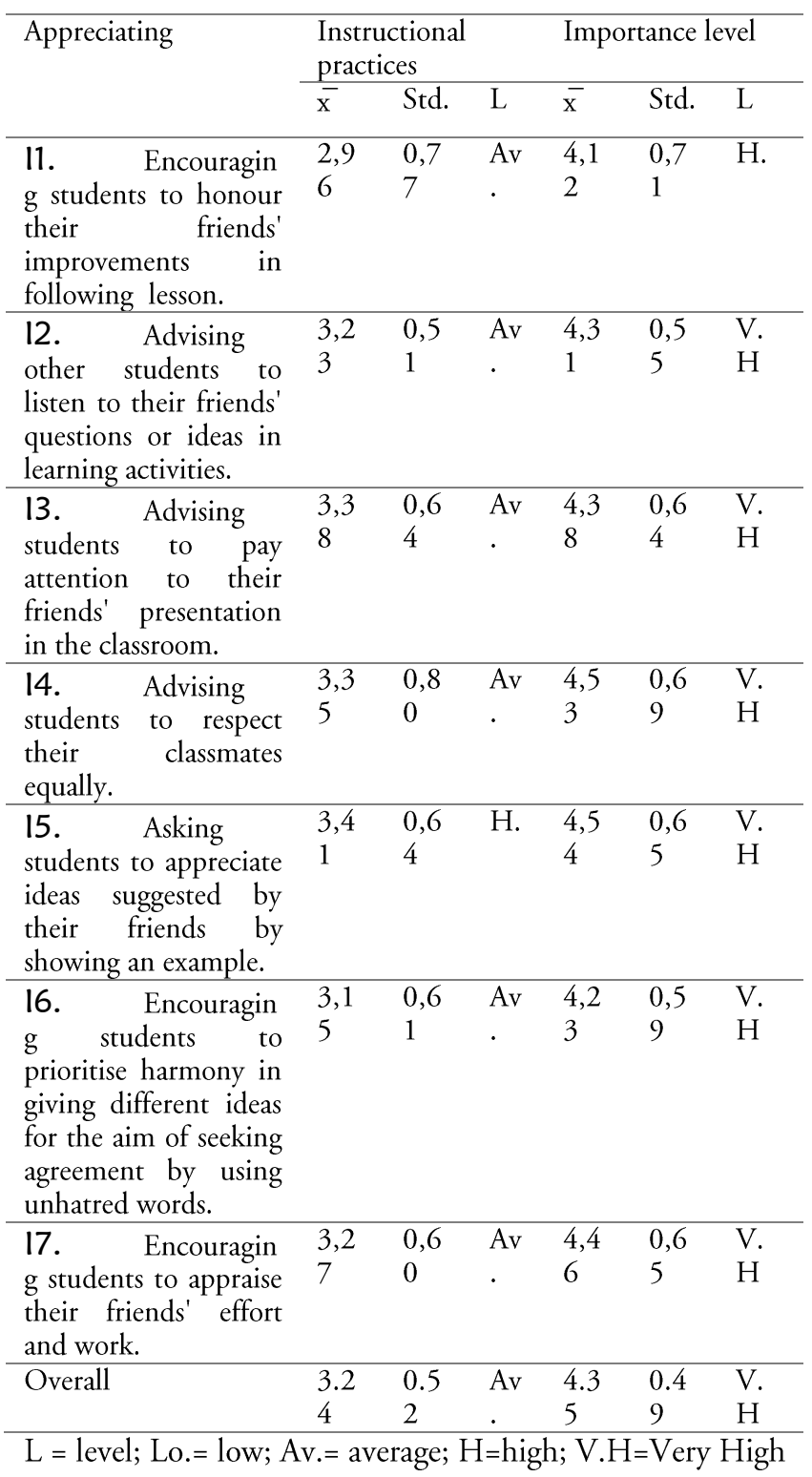


Instructional practices and importance level of Tolerance in the Learning Process

Table 3 shows that overall and all tolerance mean score indicators are average (mean score 2.41 - 3.20). This finding signifies that the teachers' instructional practices to encourage students' tolerance in the learning process were not optimal. Looking at the important level of teachers' perception, teachers perceived that tolerance (mean 4.16) is significant to be promoted through the learning process. Two appreciation indicators are rated at a very high important level; they are indicators $\mathrm{J} 1$ and $\mathrm{J} 3$. Indicators $\mathrm{J} 2, \mathrm{~J} 4$ and $\mathrm{J} 5$ are rated at a highly important level (mean 3.41 - 4.20). Teachers realised that tolerance was significant to be promoted in the classrooms.

Table 3. Mean Score of Teacher Instructional practices and Importance Level of Tolerance

\begin{tabular}{|c|c|c|c|c|c|c|}
\hline \multirow[t]{2}{*}{ Tolerance } & \multicolumn{2}{|c|}{$\begin{array}{l}\text { Instructional } \\
\text { practices }\end{array}$} & \multicolumn{4}{|c|}{ Importance level } \\
\hline & $\overline{\mathrm{x}}$ & Std. & $\mathrm{L}$ & $\overline{\mathrm{x}}$ & Std. & $\mathrm{L}$ \\
\hline $\begin{array}{lr}\text { J1. } & \text { Guiding } \\
\text { students } & \text { to } \\
\text { appreciate } & \text { different } \\
\text { ideas. } & \end{array}$ & 3.12 & 0.71 & Av. & 4.19 & 0.69 & V.H \\
\hline $\begin{array}{l}\text { J2. Asking the } \\
\text { students to } \\
\text { appreciate the } \\
\text { attitude of others } \\
\text { who are different } \\
\text { from their self. }\end{array}$ & 3.03 & 0.72 & Av. & 4.23 & 0.65 & $\mathrm{H}$. \\
\hline $\begin{array}{l}\text { J3. Suggesting } \\
\text { the students for } \\
\text { accepting the } \\
\text { different ways of a } \\
\text { group member in } \\
\text { presenting and } \\
\text { asking questions. }\end{array}$ & 3.04 & 0.72 & Av. & 4.12 & 0.65 & V.H \\
\hline $\begin{array}{l}\text { J4. Urging } \\
\text { students to } \\
\text { appreciate the } \\
\text { different ways of } \\
\text { class members in } \\
\text { completing } \\
\text { assignment. }\end{array}$ & 2.88 & 0.71 & Av. & 4.04 & 0.77 & $\mathrm{H}$ \\
\hline $\begin{array}{l}\text { J5. Asking } \\
\text { students for } \\
\text { accepting diversity } \\
\text { in a group, for } \\
\text { instance difference } \\
\text { gender, academic } \\
\text { competence, race, } \\
\text { religion and interest. }\end{array}$ & 3.00 & 0.80 & Av. & 4.23 & 0.71 & $\mathrm{H}$ \\
\hline
\end{tabular}

\begin{tabular}{lllllll}
\hline Tolerance & \multicolumn{2}{l}{$\begin{array}{l}\text { Instructional } \\
\text { practices }\end{array}$} & & \multicolumn{4}{c}{ Importance level } \\
\cline { 2 - 7 } & $\overline{\mathrm{x}}$ & Std. & $\mathrm{L}$ & $\overline{\mathrm{x}}$ & Std. & $\mathrm{L}$ \\
\hline Overall & 3.12 & 0.71 & Av. & 4.16 & 0.58 & $\mathrm{H}$ \\
\hline $\mathrm{L}=$ level; Lo.= low; & Av.= average; $\mathrm{H}=$ high; V.H=Very High
\end{tabular}

Instructional practices and Importance Level of Discipline in the Learning Process

Overall, the teachers' instructional practices in promoting students' discipline in the learning process are at an average level (mean score 2.96). The indicators of discipline show that all indicators are rated at an average level of the mean score $(2.41-3.20)$ and there is no indicator rated at a high level and very high level. This means that the emphasis on students' discipline in the learning process was not optimal. Uniquely, teachers realised that students' discipline was highly important to be embedded in the learning process. That was shown by a mean score of discipline given by the teacher at a high level (4.18). Furthermore, teacher-rated discipline indicators number $\mathrm{K} 1$, $\mathrm{K} 2, \mathrm{~K} 3, \mathrm{~K} 7$ at a very high level, and $\mathrm{K} 4, \mathrm{~K} 5, \mathrm{~K} 6$ and $\mathrm{K} 8$ at a high level. The findings are displayed in Table 4.

Table 4. Mean Score of Instructional practices and Importance Level of Discipline

\begin{tabular}{|c|c|c|c|c|c|c|}
\hline \multirow[t]{2}{*}{ Discipline } & \multicolumn{3}{|c|}{$\begin{array}{l}\text { Instructional } \\
\text { practices }\end{array}$} & \multicolumn{3}{|c|}{ Importance level } \\
\hline & $\overline{\mathbf{x}}$ & Std. & $\mathrm{L}$ & $\overline{\mathbf{x}}$ & Std. & L \\
\hline $\begin{array}{l}\text { K1. Asking } \\
\text { students for } \\
\text { following academic } \\
\text { rules and regulations } \\
\text { at faculty }\end{array}$ & 3.27 & 0.78 & Av. & 4.35 & 0.63 & V.H \\
\hline $\begin{array}{l}\text { K2. Coming } \\
\text { into a classroom } \\
\text { before the lecture } \\
\text { time. }\end{array}$ & 308 & 0.74 & Av. & 4.31 & 0.74 & V.H \\
\hline $\begin{array}{lr}\text { K3. } & \text { Ensuring } \\
\text { students } & \text { for } \\
\text { completing } & \text { and } \\
\text { submitting } \\
\begin{array}{l}\text { assignment by the } \\
\text { deadline }\end{array}\end{array}$ & 3.27 & 0.60 & Av. & 4.50 & 0.51 & V.H \\
\hline $\begin{array}{l}\text { K4. Advising } \\
\text { students to } \\
\text { organizetheir } \\
\text { learning activities } \\
\text { daily. }\end{array}$ & 2.77 & 0.65 & Av. & 4.00 & 0.69 & $\mathrm{H}$ \\
\hline K5. Asking & 2.65 & 0.63 & Av. & 4.08 & 0.63 & $\mathrm{H}$ \\
\hline
\end{tabular}




\begin{tabular}{|c|c|c|c|c|c|}
\hline \multirow[t]{2}{*}{ Discipline } & \multicolumn{2}{|c|}{$\begin{array}{l}\text { Instructional } \\
\text { practices }\end{array}$} & \multicolumn{3}{|c|}{ Importance level } \\
\hline & $\overline{\mathbf{x}}$ & Std. L & $\overline{\mathbf{x}}$ & Std. & $\mathrm{L}$ \\
\hline $\begin{array}{l}\text { students for } \\
\text { scheduling, timing } \\
\text { and prioritising their } \\
\text { learning activities. }\end{array}$ & & & & & \\
\hline Overall & 2.96 & 0.46 & 4.18 & 0.43 & $\mathrm{H}$ \\
\hline
\end{tabular}

Instructional practices and Importance Level of Patient in Learning Process

As displayed in Table 5, the overall mean of teachers' instructional practices to encourage students' patients in the classroom is at an average level $(2,35)$. All indicators of the patient are at an average level of mean score level. There is no indicator of a patient at a high or very high level. However, teachers perceived the importance of embedding patient in the classroom at a high level (mean 3.91). One indicator of patience is rated by the teacher at an essential level. The indicator is advising students to stay in instructional practices though they failed many times (L7). The teacher perceived other patience indicators at the teacher's highly important level (mean $3.41-4.20$ ).

Table 5. Mean Score of Instructional practices and Importance Level of Discipline

\begin{tabular}{|c|c|c|c|c|c|c|}
\hline \multirow[t]{2}{*}{ Patient } & \multicolumn{2}{|c|}{$\begin{array}{l}\text { Instructional } \\
\text { practices }\end{array}$} & & \multicolumn{3}{|c|}{ Importance level } \\
\hline & $\overline{\mathbf{x}}$ & Std. & L & $\overline{\mathbf{x}}$ & Std. & $\mathrm{L}$ \\
\hline $\begin{array}{l}\text { L1. Advising } \\
\text { the students to } \\
\text { devote (give more } \\
\text { time, energy, } \\
\text { attention) themself } \\
\text { to achieve their goal } \\
\text { of learning }\end{array}$ & 3.04 & 0.66 & Av. & 4.19 & 0.57 & $\mathrm{H}$ \\
\hline $\begin{array}{l}\text { L2. Advising } \\
\text { students to hear } \\
\text { long explanation } \\
\text { and argument from } \\
\text { a student. }\end{array}$ & 2.54 & 0.51 & Av. & 3.69 & 0.55 & $\mathrm{H}$ \\
\hline $\begin{array}{l}\text { L3. Advising } \\
\text { students to accept } \\
\text { the result of } \\
\text { examination as well } \\
\text { as assignment } \\
\text { though it is quite } \\
\text { disappointing. }\end{array}$ & 2.58 & 0.64 & Av. & 3.62 & 0.90 & $\mathrm{H}$ \\
\hline $\begin{array}{l}\text { L4. Advising } \\
\text { students to maintain } \\
\text { their emotion in a }\end{array}$ & 2.85 & 0.67 & Av. & 4.08 & 0.56 & $\mathrm{H}$ \\
\hline
\end{tabular}

\begin{tabular}{|c|c|c|c|c|c|c|}
\hline \multirow[t]{2}{*}{ Patient } & \multicolumn{3}{|c|}{$\begin{array}{l}\text { Instructional } \\
\text { practices }\end{array}$} & \multicolumn{3}{|c|}{ Importance level } \\
\hline & $\overline{\mathbf{x}}$ & Std. & $\mathrm{L}$ & $\overline{\mathbf{x}}$ & Std. & $\mathrm{L}$ \\
\hline $\begin{array}{llll}\text { debating } & \text { or } & & \text { a } \\
\text { discussion. } & & & \end{array}$ & & & & & & \\
\hline $\begin{array}{l}\text { L5. Advising } \\
\text { students to stay } \\
\text { motivated though } \\
\text { they get unexpected } \\
\text { result from their } \\
\text { learning. }\end{array}$ & 2.92 & 0.39 & Av. & 4.15 & 0.54 & $\mathrm{H}$ \\
\hline $\begin{array}{l}\text { L6. Advising } \\
\text { the students to keep } \\
\text { their emotion calm } \\
\text { when their ideas } \\
\text { were against or } \\
\text { rejected strongly by } \\
\text { others. }\end{array}$ & 2.69 & 0.62 & Av. & 3.88 & 0.71 & $\mathrm{H}$ \\
\hline $\begin{array}{l}\text { L7. Advising } \\
\text { students to stay in } \\
\text { an effort though } \\
\text { they failed many } \\
\text { times. }\end{array}$ & 3.08 & 0.48 & Av. & 4.23 & 0.65 & V.H \\
\hline $\begin{array}{l}\text { L8. Advising } \\
\text { students to keep } \\
\text { working under a } \\
\text { group leader's or a } \\
\text { teacher's pressure. }\end{array}$ & 2.35 & 0.63 & Av. & 3.42 & 0.70 & $\mathrm{H}$ \\
\hline Overall & 2.75 & 0.35 & Av. & 3.91 & 0.41 & $\mathrm{H}$ \\
\hline
\end{tabular}

Instructional practices and Importance Level of Confidence in Learning Process

Table 6 shows that teachers encouraged students' confidence through instructional practices at an average level (mean score 3.28). However, teachers encourage the students to be more confident in presenting their assignment (M2) and advise students to be confident to ask a question or share their ideas without being afraid of making mistakes(M3) at a high level. The four statements of confidence were rated at an average level. Interestingly, teachers rated the importance level of encouraging students' confidence at an important level (mean 4.36). Four confidence indicators were rated at a very high critical level (M2, M3, M4 and M6). Two other indicators M1 and M5 were rated at a highly important level. This means the teachers realised that encouraging students' confidence was highly important in the learning process. 
Table 6. Mean Score of Instructional practices and Importance Level of Confidence.

\begin{tabular}{|c|c|c|c|c|c|c|}
\hline \multirow[t]{2}{*}{ Confidence } & \multicolumn{2}{|c|}{$\begin{array}{l}\text { Instructional } \\
\text { practices }\end{array}$} & & \multicolumn{3}{|c|}{ Importance level } \\
\hline & $\bar{x}$ & Std. & $\mathrm{L}$ & $\bar{x}$ & Std. & L \\
\hline $\begin{array}{l}\text { N1. Ensuring } \\
\text { students complete } \\
\text { their part as a group } \\
\text { member in a group } \\
\text { project and a } \\
\text { discussion. }\end{array}$ & 2.73 & 0.78 & Av. & 3.92 & 0.84 & $\mathrm{H}$ \\
\hline $\begin{array}{l}\text { N2. Focusing } \\
\text { the students to } \\
\text { involve totally in } \\
\text { group discussion. }\end{array}$ & 2.81 & 0.69 & Av. & 3.81 & 0.69 & $\mathrm{H}$ \\
\hline $\begin{array}{l}\text { N3. Asking a } \\
\text { student to take a } \\
\text { part as moderator in } \\
\text { classroom discussion } \\
\text { or presentation. }\end{array}$ & 2.88 & 0.65 & Av. & 3.81 & 0.69 & $\mathrm{H}$ \\
\hline $\begin{array}{l}\text { N4. Giving } \\
\text { students chance to } \\
\text { check some errors } \\
\text { and mistakes by } \\
\text { their own. }\end{array}$ & 2.92 & 0.69 & Av. & 3.92 & 0.56 & $\mathrm{H}$ \\
\hline $\begin{array}{l}\text { N5. Suggesting } \\
\text { students to revise } \\
\text { report, task or } \\
\text { assignment by their } \\
\text { self. }\end{array}$ & 2.88 & 0.59 & Av. & 3.81 & 0.63 & $\mathrm{H}$ \\
\hline $\begin{array}{l}\text { N6. Suggesting } \\
\text { a student to take a } \\
\text { role of group leader } \\
\text { in a group work or a } \\
\text { discussion. }\end{array}$ & 2.62 & 0.80 & Av. & 3.62 & 0.70 & $\mathrm{H}$ \\
\hline $\begin{array}{l}\text { N7. Ensuring } \\
\text { students to work and } \\
\text { complete individual } \\
\text { assignment by } \\
\text { themselves. }\end{array}$ & 3.04 & 0.72 & Av. & 4.19 & 0.63 & $\mathrm{H}$ \\
\hline Overall & 2.84 & 0.57 & Av. & 3.85 & 0.73 & $\mathrm{H}$ \\
\hline
\end{tabular}

\section{Instructional practices and Importance Level of Responsibility in the Learning Process}

The result shows that teacher instructional practices related to responsibility are at an average level, and all indicators of responsibility are rated at an average level of the mean score. The findings imply that students' responsibility is not strongly encouraged by the

teacher through the teaching and learning process. In contrast, teachers rated the importance of encouraging students' responsibility in instructional practices at a high level. The findings are displayed in Table 7.

Table 7 Mean Score of Instructional practices and Importance Level of Responsibility

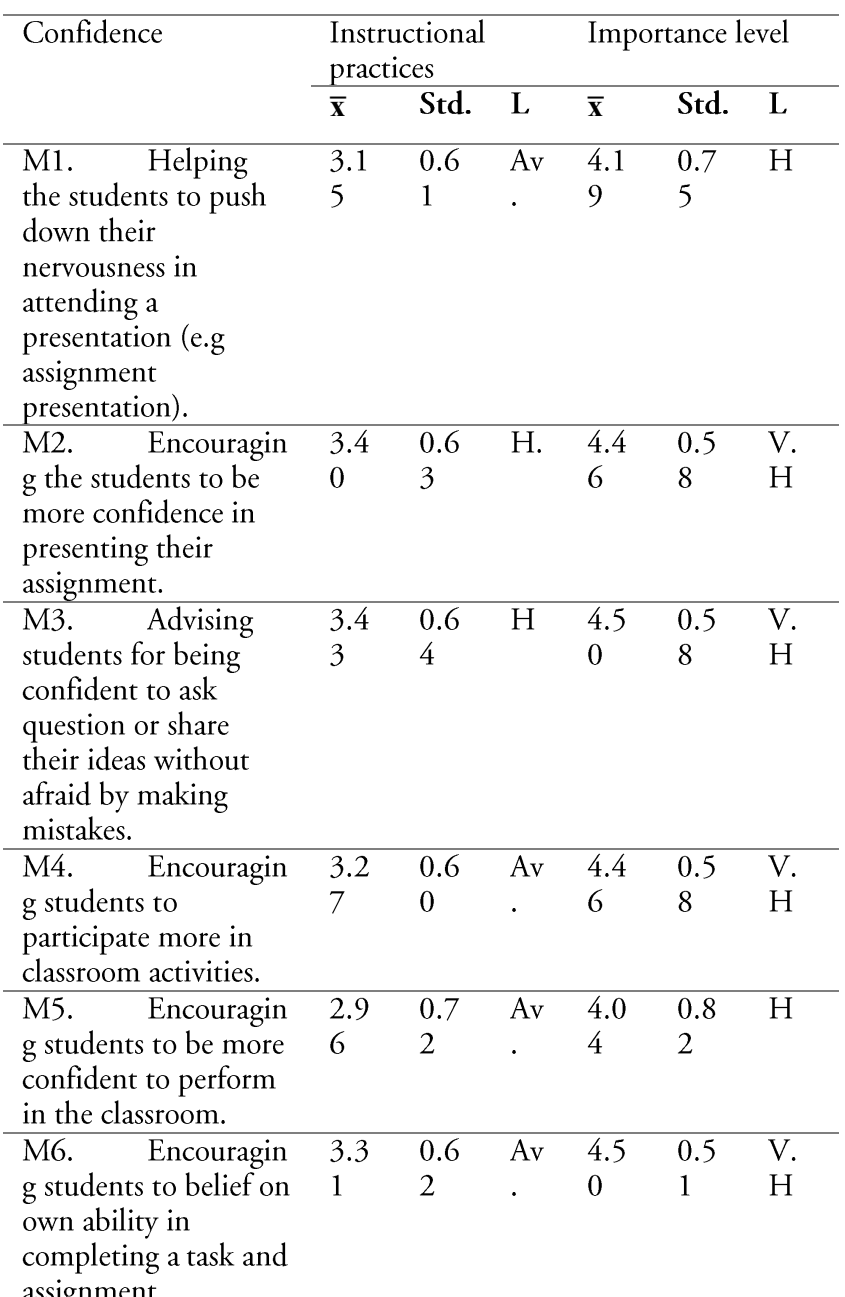

\begin{tabular}{llllllll}
\hline M7. Helping & 3.1 & 0.6 & Av & 4.1 & 0.7 & $\mathrm{H}$ \\
the students to push & 5 & 1 & & 9 & 5 &
\end{tabular}

down their

nervousness in

attending a

presentation (e.g

assignment

presentation)

$\begin{array}{llllllll}\text { M8. } & \text { Encouragin } & 3.4 & 0.6 & \mathrm{H} & 4.4 & 0.5 & \mathrm{~V} .\end{array}$

$\begin{array}{llllll}\mathrm{g} \text { the students to be } & 0 & 3 & 6 & 8 & \mathrm{H}\end{array}$

more confidence in

presenting their

assignment.

$\begin{array}{llllllll}\text { Overall } & 3.2 & 0.4 & \text { A } & 4.3 & 0.4 & \text { V. }\end{array}$

$\mathrm{L}=$ level; Lo.= low; Av.= average; H=high; V.H=Very High

\section{Teachers Problems and Suggested Solution}

Seven EFL teachers were participated in FGD to know their problems and answer gap 
appearance between their instructional practices and the importance of students' academic character development. The name of the informant is a pseudonym. The findings are reported according to the central theme.

\section{Teachers' Problems Promoting Students' Academic Character}

The FGD participants concluded that academic character was not explicitly stated in the curriculum program and syllabus design. It results in the existence of academic characters which are not being explicitly infused in instructional practices. However, the teachers revealed that they still paid attention to the students' academic character in some situations.

"Implicitly, we have built students' academic character building, for instance, checking their plagiarism, giving appreciation, but it is not in detail as a set of academic character that you show us. I think none of us here put academic character development like the one you make in our syllabus. (Rudi, male teacher)"

Further, EFL teachers also revealed that observing students' academic character was timeconsuming and it needed extra work to do;

"It is time-consuming, and we need extra work to observe students' behaviour, and most of the classes are big with more than 30 students. It is very difficult to observe (Tomy, male teacher)"

FGD participants also revealed that character values such as asking for cleaning the classroom, coming on time, using polite words to ask and responds to questions are not relevant for university students. FGD participants assumed that university students should automatically apply those characters on their own. Below are the examples of their statements;

"In my opinion, students already know and practice those characters on their own, no need for guidance from the lecturer for coming on time, cleaning the classroom, throwing garbage in the trash can, telling the right thing etc. I think it is no longer relevant for them (Ita, female teacher)"

Overloaded teaching credit units are also one of the handicaps that made teachers less focused on developing students' academic character. Most of them hold 20 hours of credit unit/week. This condition gave them a lack of preparation yet a lack of attention to students' academic character development. Example of participants' utterances as follows:

"Yes, me too. I teach 24 credit units for the semester. I know, I rarely give attention to the students' attitude, for instance, their way of giving an opinion, checking plagiarism, advising to be confident, and so on. I spend more time in preparing the material, assignment, and scoring (Wati, female teacher)"

Besides, EFL teachers had other enormous administrative burdens. For instance, as a researcher, the EFL teacher had to do research and do social service. However, they need to take official letters, ask for authority signatures, deliver the document to faculty, research centres and other offices, and many other stressful administrational issues that break their mood.

"We have to work with so many administrations; we are busy with getting some letters, for instance, letter of duty and attachment, asking authority signature, huh... too much (Yeti, female teacher)"

The last part of FGD figures out that EFL teachers are obligated to build students' academic character through teaching and learning processes such as honesty, appreciating, tolerance, discipline, patience, confidence, responsibility and other characters. 
"Yes, I agree. Developing students' academic character is task as a lecturer. As you mentioned, academic character is a part of a professional attitude that Bachelor degree must have (Resti, female teacher)"

The last part of FGD discussed participants' point of view to anticipate handicaps for developing students' academic character. In optimising students' academic character through instructional practices, participants proposed some possible problem solutions. The participants indicated that the policy needs to be made by academic authority or policymaker at the University level related to integrating and developing students' academic character through the teaching and learning process.

"I think, the university needs to make a policy dealing with academic character development and it may be stated in standard Curriculum University. (Tomy, male lecturer)"

In line with today's teaching and learning trend in the 4.0 revolution industry, participants suggested that an application of standard syllabus, online template, and guidelines that includes standard academic character should be provided. It will ease teachers in developing and integrating the academic character into a standard syllabus. Following quotations are examples of participants' utterances;

"Yes, that right provides an online guideline of inserting students' academic character in syllabus and lesson plan (Resti, female teacher)"

A Simple and practical evaluation system related to students' academic character also should be provided. University Quality Assurance Unit (LP3M) might be in charge of developing a standard evaluation system and socialising it. The participants expected that the evaluation system should be easy and practical to be used and assess students' academic character properly.

"I think, you are a researcher; you need to develop a simple and practical way to assess and evaluate students' academic character as well (Rani, Female teacher)"

FGD participants also expected that they could be free from bureaucratic and administrative burdens. They reveal that policymakers at the university level should redesign the bureaucracy and administration system to be more straightforward, fast and paperless. Therefore, teachers will have more time to work on students' progress.

"Absolutely agree, we need a simple, easy bureaucratic and online administration, a policymaker at University must think about this (Resti, female teacher)"

Some voices of worries about human character that will be neglected from the teaching and learning process in the 4.0 revolution industry seem to have some factual evidence (Woo, 2018). The current study reveals that developing students' academic character through teaching and learning is not yet emphasised by EFL teachers. The academic character, appreciating, confidence, tolerance, discipline, responsibility, honesty, and patience are only at average level. In contrast, EFL teachers realised that students' academic character development needs to be embedded through the learning process. Becoming the key factor in building students' academic characters, teachers' teaching and learning competencies should be developed, refreshed, and updated. EFL teachers are demanded to be more seriously exposed to academic character practices during learning activities (Hadiyanto, 2019a; Bath Smith, \& Swann, 2004).

FGD results show some factors affecting the EFL teachers in integrating academic character in the learning process. First, the academic 
character was not yet firmly applied in the curriculum program. It was revealed that there was no explicit statement, no guidance and standard syllabus for infusing Character education in the curriculum program. Second, according to participants, observing students' academic character was time-consuming and needed extra work to do. Third, some indicators and components of character were not relevant anymore for university students. The students should know and practice the values on their own without any guidance from an EFL teacher. Next, EFL teachers' teaching loads was one of the problems that made teachers have less focus on students' academic character development. Then, unexpected administration commitments suddenly broke teachers' concerns and focus on students' learning activities. For instance, EFL teachers often received a call, WhatsApp and direct massage to complete some administration requirements as soon as possible. However, participants realised that developing students' academic character such as honesty, appreciating, tolerance, discipline, patience, confidence and responsibility through the teaching and learning process were stated in the strategic plan of Universitas Jambi (UNJA, 2014) and Higher Education national curriculum (Ristekdikti, 2015).

On the other hand, the quantitative findings revealed that academic character was essential to be integrated through instructional practices. The findings were relevant to the current issues, which stated graduate job seeker and employee must have a good character (Woo, 2018; Bialik, Fadel and Horvathova, 2015). While Iqbal Ahmad, Hamdan Said, Alam Zeb, Sihatullah, Khalil ur Rehman (2013) argued that one of the professional teachers must have a high standard of attitude as he is the role model for their students. DIKTI (2011) also stated that university graduates must come out with professional competencies, and a good character as it is one of the essential parts of professional competencies that the students must have. To obtain the professional competencies, the academic character should be embedded in the program curriculum, syllabus and instructional activities in face-to-face class and online learning.

To optimise students' academic character through instructional practices, the participants suggested that a policy be related to integrating developing students' academic character in the curriculum, syllabus, and learning activities. Hadiyanto (2019b), and Person, Ann, Moiduddin, Hague-Angus, and Malone (2009) suggested that universities need to infuse professional character in their curriculum, and authorities should make a policy of academic. Participants also suggested that the university provide an online standard syllabus application and guidelines or online template that includes students' academic character development standards. This way will simplify and ease the EFL teachers in designing their course syllabus. By that, teachers can give more attention to students' academic character development. A standard evaluation system of students' academic character through learning activities also should be provided. It is expected that the evaluation system is practical and straightforward to be applied. The last problem solution proposed by participants was releasing EFL teachers from bureaucracy and administration burden. The innovation of bureaucracy and administration should be initiated and implemented as soon as possible.

\section{Limitation of the Study}

EFL teachers' surveys revealed that academic character was developed through instructional practices at an average level. However, the findings were not supported by students' perception, and further research needs to be conducted to investigate students' perception of their academic character development through 
the learning process. Follow-up investigations such as observation, document and syllabus content analysis were not yet conducted due to time and resources constraints. Investigating and triangulating from various data resources might be supported and will be vigorous findings of the study.

The definition, component and theoretical concept of students' academic character development was developed based on theoretical analysis from various perspective, and it was not explicitly stated and described in Indonesian Higher Education Curriculum. Indicators of academic character were developed based on theoretical analysis and related instruments such as Derlina Sabani Satria Mihardi (2015) and Wiel Veugelers (2011). The instrument needs some improvement for official usage if it is to be applied for teaching and learning evaluation dealing with students' academic character development. Moreover, since only a few research studies are conducted dealing with students' academic character development, the comparison and discussion across previous findings are still not satisfied. Future researchers will be inspired to conduct research dealing with academic character and use this article as one of reference.

\section{Conclusions}

This study was conducted at a Department of English Education search on teachers' instructional practices in students' academic character development through the teaching and learning process. This research concludes that EFL teachers perceived their instructional practices dealing with students' character development was at average level. However, they rated the importance of students' academic character was at very high level. The FGD participants revealed that they had five challenges in implementing academic character through instructional practices, namely; a) academic character was not yet firmly applied in curriculum program; b) time consuming and need extra attention; c) teachers' assumed that University students should automatically applied academic character by their own; d) overload of teaching credit unit and; e) enormous administrative burden. Participants confessed that building students' academic characters such as honest, appreciate, tolerance, discipline, patience, confidence and responsible through the teaching and learning process are their task. As a result, the teacher proposed problem solutions as follows: that policies need to be made by the academic authority at the university level, providing a standard syllabus application or online template, providing a simple evaluation system and freeing EFL teachers from bureaucratic and administrative burdens. Finally, the present study contributes to the issues surrounding the development of students' academic characters from a perspective of a university in Indonesia, and its results may be used to inform and support the data for further research in the issues of academic character development in revolution industry 4.0.

\section{References}

Bath, D. Smith, C. Stein, S. and Swann, R (2004) Beyond mapping and embedding graduate attributes: bringing together quality assurance and action learning to create a validated and living curriculum Higher Education Research \& Development. 23:3: 313-328.

Berkowitz, W., M and Bier, M. (2004). Research-Based Character Education. The Annals of the American Academy of Political and Social Science. ANNALS, AAPSS. 591: pp 72-86.

Bialik, M. Bogan, M. Fadel, C. and Horvathova, M. (2015). Character Education for the 
21st Century: What Should Students Learn? Survey of Outcomes Measurement in Research on Character Education Programs. Center for Curriculum Redesign Boston, Massachusetts. www.curriculumredesign.org

Derlina, Sabani, Satria, Mihardi (2015). Improved Characters and Student Learning Outcomes Through Development of Character Education Based General Physics Learning Model. Journal of Education and Practice. 6 (21): 162-170.

DIKTI. 2011. Kerangka Kualifikasi Nasional Indonesia. Kajian Tentang Implikasi dan Startegi Implimentasi KKNI. http://penyelarasan.kemdiknas.go.id/uploa ds/file/Buku\%20Qualification\%20Framew ork\%20DIKTI.pdf

Djailani, A., R (2013). Strategy Character Building of Students at Excellent Schools in the City of Banda Aceh. IOSR Journal of Research \& Method in Education. 1 (5): 49-59.

Fogarty, R. \& Stoehr, J. (2008). Integrating curricula with multiple intelligences (2nd ed.). Thousand Oaks, CA: Corwin Press.

Hadiyanto, (2019b). Constructing A Prototype of Developing Students' 21st Century Skills; Soft Skills, Hard Skills and Competiveness at a University in Indonesia. ICEMS 2019, pp.1-8. https://eudl.eu/pdf/10.4108/eai.30-92019.2291171

Hadiyanto, Fajaryani, N., \& Masbirorotni (2018). Constructing the measurement of EFL students' core competencies practices in learning activities. TOJET, 17(3): 1625.

Hadiyanto, H. (2019a). The EFL Students' 21st Century Skill Practices through E-Learning
Activities. IRJE (Indonesian Research Journal in Education). 3(2): 461-473.

Hair, J.E., Anderson., R.E. Tatham, R.L. \& Black, W.C. (2006). Multivariate Data Analysis. Ed .5th. Upper Saddle River: Prentice Hall.

Iqbal Ahmad, Hamdan Said, Alam Zeb, Sihatullah, Khalil ur Rehman (2013). Effects of Professional Attitude of Teachers on their Teaching 3 Performance: Case of Government Secondary School Teachers in 4 Malakand Region. Journal of Educational and Social Research. 3: pp.25 - 31. Doi: 10.5901/jesr.2013.v3n1p25

Kemendiknas. (2011). Panduan Pendidikan Karakter. Jakarta: Badan Penelitian dan Pengembangan Pusat Kurikulum dan Perbukuan.

Kementerian Pendidikan (2010). Pengembangan Pendidikan Budaya dan Karakter Bangsa: Pedoman Sekolah. Jakarta: Puskur. Balitbang Kemendiknas.

Lapsley, D. K., \& Narvaez, D. (2006). Character Education. In K. A. Renninger, I. E. Sigel, W. Damon, \& R. M. Lerner (Eds.), Handbook of child psychology: Child psychology in practice (p. 248-296). John Wiley \& Sons Inc. https:/www.researchgate.net/publication/ 227555957_Character_Education.

Pallant, J. (2011). A Step by Step Guide to Data Analysis Using SPSS Program. Survival Manual. 4th Edition. China: Everbest Printing.

Person, Ann, E. Moiduddin, M. Hague-Angus, M. and Malone, L.M. (2009). Survey of Outcomes Measurement in Research on Character Education Programs (NCEE 2009-006)," Washington, DC: National Center for Education Evaluation and Regional Assistance, Institute of Education 
Sciences, U.S. Department of Education. This report is available on http://ies.ed.gov/ncee/pdf/2009006.pdf

Ristekdikti (2015). Standar nasional pendidikan tinggi direktorat penjaminan mutu. Retrieved from: http://bpm.umsida.ac.id/wpcontent/uploads/2017/08/3.-StandarNasional-Pendidikan-Tinggi-SN-

Dikti.pdf.

Rusijono and Khotimah., K (2018). The implementation of assessment model based on character building to improve students' discipline and achievement. Universitas Negeri Surabaya. The Consortium of AsiaPacific Education Universities (CAPEU). IOP Conf. Series: Materials Science and Engineering. 296: pp. 1-5.

Trianto. 2007. Model Pembelajaran Terpadu dalam Teori dan Praktek, Jakarta: Prestasi Pustaka

UNJA. (2014). Rencana strategis bisnis Universitas Jambi 2014-2018: Menuju
Universitas Unggulan untuk Meningkatkan Daya Saing Bangsa 2025. Retrieved from https://siakad.unja.ac.id/ terpadu/dokumen/universitas/02Renstra\%20Bisnis\%20UNJA\%20\%20(20 14)\%20-\%20Lengkap.pdf.

Veugelers, W. (2011). Education and Humanism. Linking Autonomy and Humanity. Roterdam, The Netherlands: Sense Publishers. https://link.springer.com /book/10.1007\%2F978-94-6091-577-2

Vezzuto, L. A. (2004). How Young People Develop Character: A Conceptual Framework with Descriptions of Promising Practices. Institute for Character Education: Instructional Services Division, Learning Support Unit.

Woo, S., H. (2018). Attitudes and Performance of Workers Preparing for the Fourth Industrial Revolution. KSII Transactions on Internet and Information Systems. 12 (8): pp. $4038-4056$. 